\title{
Dag van respect voor de zorg
}

\section{Op 26 januari was het de Dag van het respect voor de zorg. Verpleegkundigen en andere zorgverleners lieten hun licht schijnen op werkplezier in en na coronatijd.}

tekst Jeroen Wapenaar fotografie Arno Massee

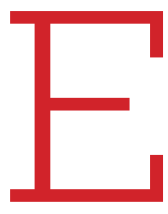

$\mathrm{lk}$ jaar in januari ontvangt een initiatief dat werkplezier in de zorg bevordert de Nationale HR Zorg Award. Dat gebeurt op de Dag van het werkplezier in de zorg, georganiseerd door onderzoeks- en adviesbureau FWG Progressional People. Dit jaar kregen álle ingestuurde initiatieven die werkplezier bevorderen (ruim 40) een prijs uitgereikt. Ook was er aandacht voor inspirerende activiteiten van zorgverleners op social media.

De dag waarop dit plaatsvond (zie kader) was dit jaar omgedoopt tot Dag van het respect voor de zorg. 'Omdat we door te laten zien hoe veerkrachtig zorgverleners zijn, hopen dat heel Nederland ook na de pandemie onthoudt hoeveel respect de zorg hoort te krijgen', zegt Sabine Uitslag, directeur Werkplezier in de zorg van FWG Progressional People. 'En daarmee bedoelen we álle zorg. In ons online symposium hebben we vertegenwoordigers van de thuiszorg, gehandicaptenzorg en ggz als eerste laten uitleggen hoe corona hun werk verandert. Die sectoren zijn echt onderbelicht gebleven', vindt
Uitslag, voormalig verpleegkundige, bestuurder en politica.

\section{De Gommers voor de thuiszorg}

Wijkverpleegkundige Ilse Sluiter doet deze extra aandacht goed. 'Wat verpleegkundigen en andere zorgverleners in de thuiszorg meemaken zou vaker benoemd mogen worden. Zoals hoe frustrerend het is als je cliënten moet vertellen dat

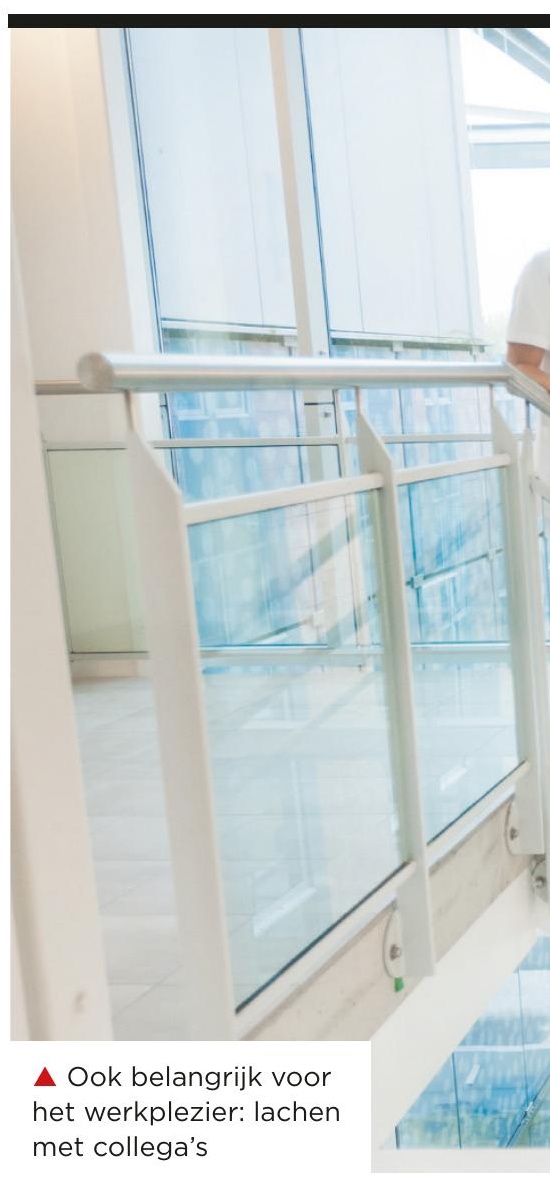

dat niet prettig. Hoe cliënten zich voelen bepaalt voor een groot deel het humeur van verpleegkundigen. Bovendien hol je in deze maanden in de thuiszorg in je eentje soms een hele dag achter de feiten aan', zegt Sluiter. 'Eigenlijk moet

\section{'Dat is ook werkplezier: voelen dat we de opdracht waar we voor staan samen aangaan'}

door de coronacrisis de zorg tijdelijk minder of anders wordt. Natuurlijk kijken we nog steeds heel zorgvuldig naar wie wat nodig heeft. Maar als je cliënten zonder covid-19 moet vertellen dat ze minder vaak kunnen douchen omdat meer zorgverleners in het coronateam nodig zijn, of dat ze geen zorg krijgen op de hun vertrouwde momenten, dan is de thuiszorg ook een Diederik Gommers hebben die voor ons opkomt op tv.'

\section{Persoonlijke interesse}

Maar Sluiter doelt met meer aandacht ook op factoren die het werkplezier in de thuiszorg verhogen. Een collega wil zich specialiseren in de wondzorg, maar in de vacatures voor een wondverpleeg- 


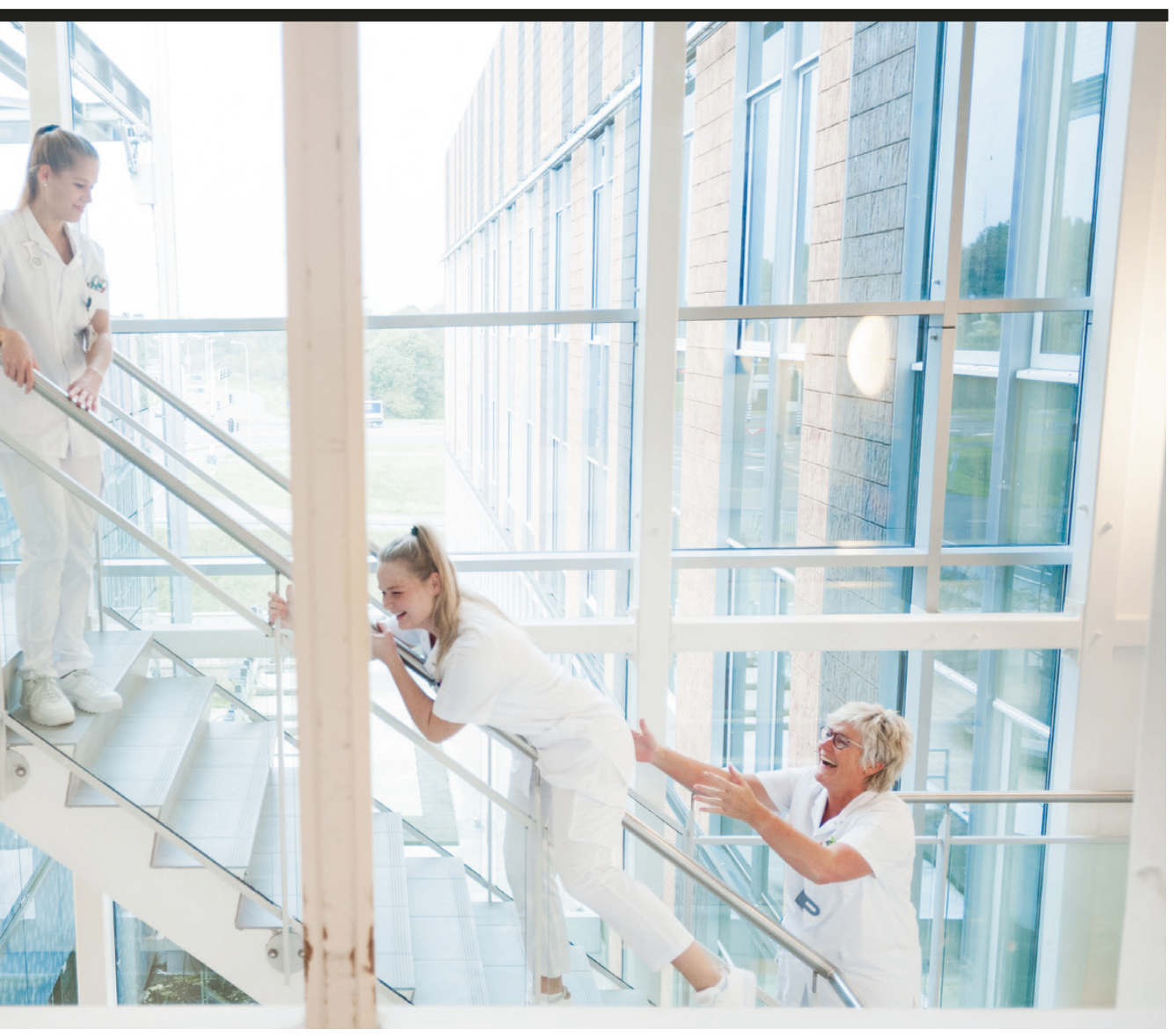

kundige wordt bij onze organisatie steeds gevraagd naar hbo-niveau. $\mathrm{Zij}$ moet voor specialisatie dus eerst de hbo-v doen. Voor haar is dat om allerlei redenen een drempel. Misschien zou ze met alleen een aanvullende studie in wondzorg wel een heel goede wondverpleegkundige kunnen worden. Qua ontwikkelmogelijkheden zou het best wat flexibeler kunnen in de thuiszorg.'

Vanuit haar organisatie wordt veel gedaan om de thuiszorgmedewerkers te ondersteunen, benadrukt Sluiter. 'De bestuursleden komen nu met videoboodschappen, waarin ze benadrukken hoe trots het bestuur op ons is. Dat geeft niet alleen erkenning, maar maakt ook dat je bestuurders een gezicht krijgen en je ze gemakkelijker aanspreekt. Bevorderlijk voor het werkplezier in de wijk is ook om in het teamoverleg standaard te informeren naar elkaars persoonlijke situatie. Wij noemen dat rondje p: iedereen vragen of hij of zij nog wat kwijt wil.
Of dat nu is dat je oma is overleden, je dochter jarig is of je een nieuwe hobby hebt ontdekt. Dat klinkt misschien logisch, maar omdat je zoveel alleen bent is het extra fijn als je regelmatig zo'n gesprek hebt.'

\section{Fit blijven}

Op de Dag van het respect voor de zorg was er ook aandacht voor lichamelijke en mentale fitheid. Bijvoorbeeld aan de hand van Antoniusfit.nl van St. Antonius Ziekenhuis Utrecht/Nieuwegein. Dit digitale platform ontstond aan het begin van de coronacrisis en bevat inspiratie rondom bewegen, voeding en ontspanning. Voorbeelden zijn tips voor een kinderverjaardag in coronatijd, ideeën voor virtuele activiteiten (online escaperoom, virtuele rondleidingen), mindfulness en gezonde recepten.

\section{Collega's leren kennen}

Antonius Fit komt voort uit Sterk in je

\section{KIJK HET ONLINE EVENT GRATIS TERUG}

Op de Dag van het respect voor de zorg, 26 januari 2021, was er een online event met diverse sprekers. Verpleegkundigen, bestuursvoorzitters, maar bijvoorbeeld ook Diederik Gommers gingen in op werkplezier in de zorg, in en na coronatijd. Het event is gratis terug te kijken op fwg.nl (zoek op werkplezier).

Werk, een programma van het ziekenhuis om medewerkers vitaal, bekwaam en gemotiveerd te houden, zegt hr-adviseur Sterk in je Werk Judith Winkel. 'We willen alle medewerkers van het ziekenhuis (op locatie of thuis) kunnen blijven bereiken en inspireren om in beweging te blijven en goed voor zichzelf te zorgen, fysiek en mentaal. Naast de inspiratie voor individuele medewerkers bieden we ook activiteiten en challenges aan die voor verbinding zorgen tussen collega's, ook al is dat op afstand. En dat vergroot ook het werkplezier, want iedereen voelt: we doen deze opdracht echt samen.' Regieverpleegkundige en voorzitter van de VAR Annette van Duijn geeft een voorbeeld. 'Bij Steptember (steptember.nl) is het de bedoeling elke dag in september 10.000 stappen te zetten, waarbij je elkaar in teamverband kunt uitdagen. Dit gaf leuke competitie en eens een ander praatje bij de koffie dan covid-19.'

De coronacrisis heeft laten zien dat iedereen de zorg met elkaar levert, van zorgverleners tot ondersteunende diensten als schoonmaak en roomservice en ook de ict, benadrukt Van Duijn. 'Een voorbeeld is het aanpassen van het EPD. We behandelen in ons ziekenhuis covid19-patiënten als patiënten die risico hebben op ondervoeding, waarvoor ze standaard energie- en eiwitverrijkte voeding krijgen. Dankzij de ict-collega's verschijnt bij deze patiënten niet meer continu een pop-up over screenen op ondervoeding in het EPD. Daarmee zorgen ze ervoor dat we efficiënter werken, en dus met meer plezier.' 